\title{
ANTIDIABETIC EFFECTS OF INDONESIAN BAY LEAVES (SYZYGIUM POLYANTHUM) EXTRACTS THROUGH DECREASING ADVANCED GLYCATION END PRODUCTS AND BLOOD GLUCOSE LEVEL ON ALLOXAN-INDUCED HYPERGLYCEMIC WISTAR RATS
}

\author{
SRI WAHJUNI*, A A I A MAYUN LAKSMIWATI, IDA BAGUS PUTRA MANUABA \\ Department of Chemistry, Faculty of Mathematics and Natural Sciences of Udayana University, Denpasar, Bali, Indonesia.
} Email: sriwahjunimanuaba@gmail.com

Received: 02 December 2017, Revised and Accepted: 15 January 2018

\section{ABSTRACT}

Objective: Increased production of reactive oxygen species is one of the causes of hyperglycemia. This study aims to determine the effectiveness of Indonesian bay leaves (Syzygium polyanthum) extracts as an antidiabetic agent in decreasing blood glucose and advanced glycation end products (AGEs) level of alloxan-induced hyperglycemic Wistar rats.

Methods: This research is a real experimental study with pre- and post-test control group design. The study begins with the induction of hyperglycemia in 40 Wistar rats using alloxan. Subsequently, hyperglycemic rats were divided into 6 groups, namely, the positive control group (P0); the treatment group by not giving the intake of Indonesian bay leaf (P1); the treatment group was given the extract of Indonesian bay leaves (S. polyanthum) $0.5 \mathrm{mg} / \mathrm{kg}$ body weight/day (P2); treatment group given Indonesian bay leaves extract $2.0 \mathrm{mg} / \mathrm{kg}$ body weight/day (P3); treatment group given Indonesian bay leaves $5.0 \mathrm{mg} / \mathrm{kg}$ body weight/day (P4), and P5 was treatment group with glibenclamide (hyperglycemia-lowering medication).

Results: In the treatment of P1, P2, P3, P4, and P5 groups, it can be seen that there are decreases of blood glucose and AGEs level between pre- and post-test comparison. However, the most significant drop in mean plasma glucose level was observed at the dosage 5.0 mg kg-1 (P4).

Conclusion: The administration of Indonesian bay leaf extracts at a dose of $5.0 \mathrm{mg} / \mathrm{kg}$ body weight/day have an antidiabetic effect through decreasing blood glucose and AGEs level in alloxan-induced hyperglycemic Wistar rats.

Keywords: Indonesian bay leaves (Syzygium polyanthum), Blood glucose, Advanced glycation end products, Hyperglycemia.

(c) 2018 The Authors. Published by Innovare Academic Sciences Pvt Ltd. This is an open access article under the CC BY license (http://creativecommons. org/licenses/by/4. 0/) DOI: http://dx.doi.org/10.22159/ajpcr.2018.v11i4.24084

\section{INTRODUCTION}

Hyperglycemia is a complex chronic disease that encompasses carbohydrate, protein, and fat metabolism abnormalities and the development of microvascular, macrovascular, and neurologic complications characterized by diabetes mellitus. Diabetes mellitus is a group of various defects characterized by the problem of sugar content that is hyperglycemia. Hyperglycemia is a condition in which an elevated fasting blood glucose level of the patient is above $110 \mathrm{mg} / \mathrm{dL}$ and blood glucose $2 \mathrm{~h}$ postprandial above $140 \mathrm{mg} / \mathrm{dL}$. Determination of normal blood sugar levels was based on the 2012 PERKENI reference [1,2]. Diabetes mellitus has characteristics of insulin deficiency and/or impaired function or insulin effect, causing hyperglycemia, carbohydrate, fat, and protein metabolism disorders, beginning with no glycosylation reaction that starts with reversible Schiff base formation, which will undergo rearrangement, to form the amadori product [3]. This stable amadori product undergoes a series of reactions with the intermediate compound of dicarbonyl forming the advanced glycation end products (AGEs).

In general, people with hyperglycemia also found an inflammatory reaction due to the ease of the patient having an infection. Ongoing inflammation may increase the release of pro-inflammatory cytokines such as tumor necrosis factor (TNF- $\alpha$ ). In addition to the increase in TNF- $\alpha$, there is also a decrease in adiponectin leading to insulin resistance. On prolonged insulin resistance, the pancreas cells are no longer able to compensate for insulin hence hyperglycemia. Hyperglycemia and excessive release of free fatty acids will be the ingredients for the generation of triglycerides in the liver [4]. The autoxidation process in hyperglycemia and glycemic reaction results in the release of electrons. The release of these electrons will trigger the formation of free radicals, especially superoxide radicals and hydrogen peroxide, and by Haber-Weis and Fenton's reaction, will form hydroxyl radicals. These ingredients are known as oxygen-free radicals that can damage cell membranes, into lipid peroxides known as malondialdehyde. In diabetes mellitus, the reaction begins with a state of hyperglycemia, which further increases Schiff base formation between aldehyde glucose groups and protein amine groups. These non-enzymatic reactions, after 24-48 h, will cause a rearrangement of the Schiff base to a more stable form $[5,6]$.

Syzygium polyanthum is widely used in Indonesian and Malaysian cuisines and is also traditionally used in the treatment of diabetes in Indonesia. This plant, belonging to Myrtaceae family, is widely distributed throughout Burma (Myanmar), Indo-China, Thailand, Malaysia, and Indonesia (Java, Sumatera, and Kalimantan). Phytochemical screening showed that its leaves contained essential oils, tannins, flavonoids, terpenoids, and fatty acids. Interestingly, Patel et al. reported that the antidiabetic activity of medicinal plants was attributed to the presence of polyphenols, flavonoids, terpenoids, and coumarins [7].

This study conducted to determine the effectiveness of Indonesian bay leaves ( $S$. polyanthum) extracts as an antidiabetic agent in decreasing blood glucose and AGEs level of alloxan-induced hyperglycemic Wistar rats.

\section{METHODS}

\section{Materials}

The research material used was Indonesian bay leaves extracts. Wistar rats blood was taken from orbital sinus using syringe size of $3 \mathrm{~mL}$. Then ethanol, aquadest, glucose kit and AGEs test were needed for blood glucose examination. Gas chromatography-mass spectrometry 
(GC-MS) is a fusion of GC-MS. Compounds that have been separated by GC are further detected or analyzed using mass spectroscopy. GCMS for phytol compounds has a typical split injection condition with a 1:15-1:100 split-dissolution ratio, a $250-300^{\circ} \mathrm{C}$ injection temperature, pre-heated column temperature of $250-300^{\circ} \mathrm{C}$, and corresponding to the isocratic and temperature conditions in the column heater that have been programmed. GC-MS detected Indonesian leaves extracts containing phytol, in ethanol extract of Indonesian bay leaves, was detected at $2.41 \%$ abundance as green leaves, with running condition injection $280^{\circ} \mathrm{C}$, helium carrier gas with pressure of $149.9 \mathrm{Kpa}$, and flow rate $2.77 \mathrm{~mL} / \mathrm{min}$ on GC-MS QP-2010 merkShimadzu tool [8].

\section{Equipment}

The equipment used in the study is a glucose kit, GC-MS, a set of glasses, analytical balance and syringe, a set of ultraviolet-visible variant DMS 80 spectrophotometer tools, and Clements 2000 injection syringes.

\section{Research methods}

This research is true experimental research with randomized pre- and post-test control group design [9]. Ethical clearance of this study was approved by the Ethics Committee for The Use of Animals for Research and Education on May $9^{\text {th }}, 2017$ with letter number of 291/KEPH-Lit-4/V/2017. The first step was to make the condition of Wistar rats uniform, then the 40 Wistar rats being standardized for a week, then made hyperglycemia condition with high-fat diet and alloxan induction for 7 weeks (data pretest). In the next step, 40 Wistar rats were divided into 6 treatments, i.e., P0 (positive control), P1 without giving the extract of Indonesian bay leaves, $\mathrm{P} 2$ treatment giving $0.5 \mathrm{mg} / \mathrm{kg}$ body weight, P3 giving of Indonesian bay leaves extracts of $2.0 \mathrm{mg} / \mathrm{kg}$ body weight/day, P4 giving leaves extracts of Indonesian bay $5.0 \mathrm{mg} / \mathrm{kg}$ body weight/day, and P5 administration of glibenclamide at $0.18 \mathrm{mg} /$ day $/ 200 \mathrm{~g}$ body weight for 8 weeks (data post-test). The data of this research are statistically analyzed by Post Hoc Test to know whether a variable is normal or not normal. If the data distribution is normal and homogeneous with $\mathrm{p}>0.05$, then the analysis is continued with parametric analysis of ANOVA method using SPPS (Statistical Product and services solution) program at $95 \%$ confidence level. Furthermore, post hoc study Tukey/ HSD test is used to determine which groups have the same or different effects with each other [10]

\section{RESULTS}

In this study of hyperglycemia, authors prepared forty Wistar rats. The weight of the Wistar rats was also weighed 3 times, i.e., the beginning of the 4-week-old rats trial, after high-fat feeding for 7 weeks, then induced alloxan every week as much as $125 \mathrm{mg} / \mathrm{kg}$ body weight/day (pre-test), and for 8 weeks, obtained leaves extract with a variation of administration is then checked for decreased blood glucose and AGEs (posttest). Data of decrease in blood glucose level of hyperglycemic Wistar rats pre- and post-test are shown in Table 1.

Table 1 shows that the normality and homogeneity tests are all normal distributed and the variants homogeneous with $p>0.05$. Furthermore, to know the difference of treatment of Indonesian bay leaves extract to decrease blood glucose level, it can be done only by comparing preand post-test data $(p<0.05)$. The most significant drop in mean plasma glucose level was observed at the dosage $5.0 \mathrm{mg} / \mathrm{kg}$ which decrease blood glucose level $65.91 \%$ than control. It hypoglycemic effect was found to be higher compared to glibenclamide at $0.18 \mathrm{mg} /$ day $/ 200 \mathrm{~g}$ body weight.

Table 2 shows that the normality and homogeneity tests were all normal distributed and the variants homogeneous with $\mathrm{p}>0.05$. Furthermore, to know the difference of the treatment of Indonesian bay leaves extract on the decrease of blood AGEs level, it can be done only by comparing pre- and post-test data $(\mathrm{p}<0.05)$. The most significant drop in mean plasma AGEs level was observed at the dosage $5.0 \mathrm{mg} / \mathrm{kg}$ which decreases blood glucose level $20.27 \%$ than control. Its ability to decrease teh AGEs level was found to be higher compared to glibenclamide at $0.18 \mathrm{mg} / \mathrm{day} / 200 \mathrm{~g}$ body weight.

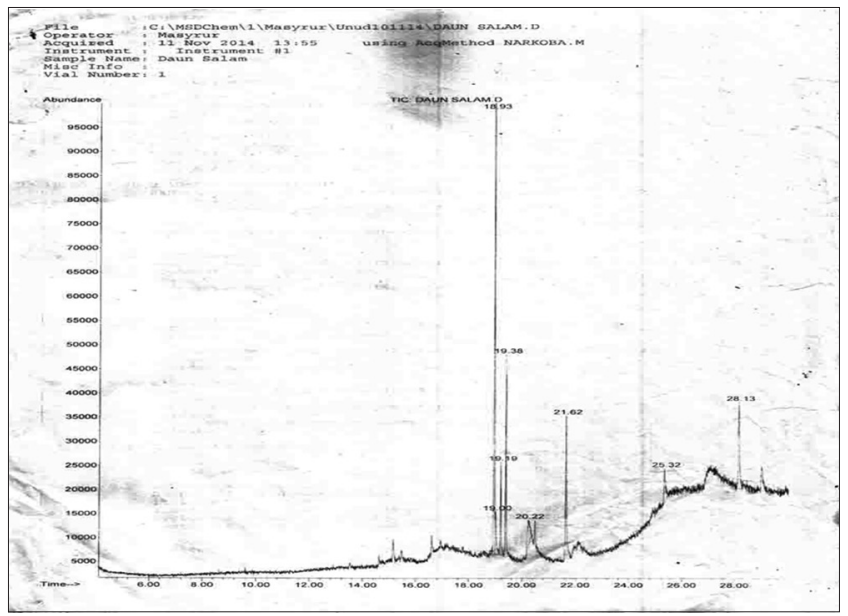

Fig. 1: Chromatogram of the active compounds of Syzygium polyanthum

Table 1: Blood glucose decreases in hyperglycemic wistar rats

\begin{tabular}{lll}
\hline \multicolumn{2}{l}{ Observation of blood glucose level $(\mathbf{m g} / \mathbf{d L})$} & \\
\hline Treatment & Pretest & Posttest \\
\hline P0 & $109.35 \pm 3.03$ & $105.76 \pm 2.53$ \\
P1 & $320.33 \pm 3.06$ & $218.60 \pm 3.25$ \\
P2 & $257.21 \pm 2.19$ & $173.59 \pm 2.99$ \\
P3 & $249.41 \pm 2.77$ & $128.59 \pm 1.88$ \\
P4 & $248.61 \pm 2.07$ & $110.56 \pm 1.68$ \\
P5 & $340.61 \pm 2.73$ & $151.69 \pm 2.03$ \\
\hline
\end{tabular}

Table 2: AGEs products decreases in hyperglycemic wistar rats

\begin{tabular}{lll}
\hline \multicolumn{2}{l}{ Observation of blood AGEs level $(\mathbf{m g} / \mathbf{d L})$} & \\
\hline Treatment & Pre-test & Post-test \\
\hline $\mathrm{P}_{0}$ & $0.135 \pm 3.03$ & $0.127 \pm 2.53$ \\
$\mathrm{P}_{1}$ & $0.224 \pm 3.06$ & $0.218 \pm 3.25$ \\
$\mathrm{P}_{2}$ & $0.220 \pm 2.19$ & $0.216 \pm 2.99$ \\
$\mathrm{P}_{3}$ & $0.209 \pm 2.77$ & $0.205 \pm 1.88$ \\
$\mathrm{P}_{4}$ & $0.148 \pm 2.07$ & $0.118 \pm 1.68$ \\
$\mathrm{P}_{5}$ & $0.167 \pm 2.73$ & $0.156 \pm 2.03$ \\
\hline
\end{tabular}

AGEs: Advanced glycation end

The leaves of S. polyanthum were successfully extracted and analyzed using GC-MS. The result of GC-MS analysis of showed eight peaks of compounds with different retention (tR), as shown in Fig. 1 with a retention time (tR), peak area (\%), and molecule weights is presented in Table 3. The retention time showed 18.93 which indicates a function to modulate the transcription factor peroxisome proliferator-activated receptor-alpha retinoid receptor X. Eight major compounds contained in the extract are shown in Table 3 which majority is the precursor of chlorophyll. The highest peak was found to be the phytol group.

\section{DISCUSSIONS}

Forty Wistar rats have been studied for the study of hyperglycemia. The hyperglycemia study was performed by giving a high amount of fat diet for 7 weeks accompanied by alloxan every week as much as $125 \mathrm{mg} / \mathrm{kg}$ body weight. The Wistar rats was weighed, i.e., the beginning of the experiment (the age of the 4-week Wistar rats), after a weekly supplement feeding of alloxan-induced fat, and for 8 weeks also administered extract of Indonesian bay leaves (posttest). The mean of initial weight of Wistar rats (age 4 weeks) was $49.78 \pm 0.77$ g. After hyperglycemia, the average weight of Wistar rats (pretest) was $200.75 \pm 0.51 \mathrm{~g}$. The average weight of Wistar rats (post-test) for 8 weeks was $196.50 \pm 1.05 \mathrm{~g}$. 
Table 3: Detected compounds in ethanol extract of $S$. polyanthum

\begin{tabular}{lllll}
\hline Peak & Retention (minute) & Area (\%) & Molecular formula & Compounds name \\
\hline 1 & 18.93 & 37.55 & 0 & Phytol \\
2 & 19.00 & 4.50 & 0 & 2-Hexadecene, 3,7,15-tetramethyl \\
3 & 19.19 & 6.82 & 0 & (z)-1,3-phytadiene \\
4 & 19.38 & 14.06 & 0 & Cyclopentane 1-ethyl \\
5 & 20.22 & 5.70 & 0 & Cis-1,3-Dideuterio-1,3cyclo hexan \\
6 & 21.62 & 14.97 & 0 & Phytol acetate \\
7 & 25.32 & 5.17 & 0 & 1,3-dimethyl-4-azaphenanthrene \\
8 & 28.13 & 1.84 & 0 & 1-methy-2phenylindole-2-ethylacridine \\
\hline
\end{tabular}

S. polyanthum: Syzygium polyanthum

The result of extraction of $1800 \mathrm{~g}$ of Indonesian bay leaves by maceration using technical ethanol solvent $(2 \times 24 \mathrm{~h})$ was obtained ethanol condensed extract as much as $147 \mathrm{~g}$ of dark green. Extraction process with ethanol solvent intends to get all polar components. The ethanol solvent contracting the cell contents is affected by the ability to loosen the cell cellulose skeleton and dissolve the cell's active components.

The ethanol solvent can damage the cell wall, dissolve the bioactive compound, and retain the properties of the reactivity of a compound. The antioxidant capacity of 1,1-Diphenyl-2-picrylhydrazine (DPPH) ethanol extract of Indonesian bay leaves has a very high antioxidant capacity with an immersion percentage of $82.90 \%$ within 60 min. That means that the extract of ethanol of Indonesian bay leaves in the $60^{\text {th }}$ min has the ability as an inhibitor of DPPH activity which is a strong oxidizer associated with the ability as a free antiviral (free radical scavenger). Sudjatmiko states that a substance is said to be active as an antioxidant when the immersion percentage is higher than or equal to $50 \%$ [11-13].

Furthermore, it is likely caused by some compounds that are synergistic in reducing free radicals. The quercetin flavonoid compound is one of the derivatives of the quercetin flavonoid compound [14]. This study found that the provision of Indonesian bay leaves extracts with some concentrations can reduce blood glucose and AGEs levels of hyperglycemic Wistar rats. Blood glucose level and AGEs in Tables 1 and 2 can also be statistically analyzed in the control group with a Indonesian bay leaves extracts of $5.0 \mathrm{mg} / \mathrm{kg}$ body weight/day both pre- and post-test significantly decreased blood glucose and AGEs level in hyperglycemic Wistar rats.

The mechanism of Indonesian bay leaves extracts works as an antihyperglycemic in lowering blood glucose and AGEs levels; phytol compounds primarily play it through insulin secretion by $\beta$-pancreatic cells or altered glucose metabolism. Phytol plays a role in improving insulin secretion by $\beta$-pancreatic cells through mechanisms in maintaining functioning beta cells and improving pancreatic action, resulting in insulin secretion by islets of Langerhans [15-21].

Araki and Nishikawa revealed that red fruit can control blood glucose levels [22]. Two mechanisms are done in the treatment of diabetes that spurs the production of insulin and inhibits the work of alphaglycosidase enzyme where this enzyme plays a role in degrading carbohydrates that enter the body and converted into glucose. When the action of alpha-glycosidase enzyme can be inhibited, the process of converting carbohydrates into glucose can be suppressed, so there is an effect in lowering blood glucose [23-25]. Similar result demonstrated by a study of Jain et al. and Paini et al. that Prucha leaves, green tea, and Abrus precatorius extract contained flavonoid antioxidant that has a antidiabetic properties and can be used as sources of natural antioxidant and used in drug formulations for treatment of diseases resulting from oxidative stress $[26,27]$.

\section{CONCLUSION}

Considering the results of the study and discussions, it can be summarized as follows: The administration of leaves extracts of Indonesian bay (S. polyanthum) as much as $5.0 \mathrm{mg} / \mathrm{kg}$ body weight/day can decrease blood glucose and AGEs level significantly in hyperglycemic Wistar rats that induced by alloxan. Thus, it made it as a potential candidate for the new antidiabetic agent. However, further studies are needed to evaluate its dosage range and isolate the active compounds.

\section{AUTHOR CONTRIBUTION}

All authors had contributed equally to the review work.

\section{CONFLICTS OF IINTEREST}

All authors have none to declare.

\section{REFERENCES}

1. Shahab A. Diagnosis and Treatment of Diabetes Mellitus (Reviewed from Consensus of Treatment of Diabetes Mellitus in Indonesia: Perkeni 2006). Palembang: Division of Metabolic Endocrinology, Department of Internal Medicine, Faculty of Medicine of Sriwijaya University; 2006.

2. Indonesia PE. Consensus of Controlling and Preventing Diabetes Mellitus Type 2 in Indonesia. Jakarta: Indonesia PE; 2012.

3. Narayana Murthy UM, Sun WQ. Protein modification by Amadori and Maillard reactions during seed storage: Roles of sugar hydrolysis and lipid peroxidation. J Exp Bot 2000;51:1221-8.

4. Gunawan IW, Suastika K, Putra AB. Potential of Euchresta horsfieldii Lesh Benn leaf extract prevent oxidative stress through decrease of malondialdehyde levels and profile histopathology pancreatic B-cells in diabetic rats. World J Pharm Pharm Sci 2015;5:1340-52.

5. Mahley RW. Biochemistry and physiology of lipid and lipoprotein metabolism. Principles and Practice of Endocrinology and Metabolism. $3^{\text {rd }}$ ed. Philadelphia (PA): JB Lippincott; 2001. p. 1503-3.

6. Tjokroprawiro A. Diabetes mellitus in indonesian citizens. Health Res Bull 1993;21:43-62

7. Patel D, Prasad S, Kumar R, Hemalatha S. An overview on antidiabetic medicinal plants having insulin mimetic property. Asian Pac J Trop Biomed 2012;4:320-30.

8. Pamungkas B. Ethanol Extracts of God's Crown Fruits (Phaleria macrocarpa) as Natural Preservative of Guava Syrup(Doctoral Dissertation, Muhammadiyah University, Purwekerto); 2013.

9. Wahjuni S. Provision of lemuru fish oil (Sardinella longiceps) as anti dyslipidemia by increasing HDL in wistar rats. J Chem 2011;5: 156-62.

10. Santoso S. SPSS Statistical Product and Service Solutions. Jakarta: PT. Elex Media Komputindo; 1999. p. 300-80.

11. Sujatmiko B. Degradation of Tannin Compound, Fitic Acid, Antitrypsin and Increased In Vitro Digestibility of Protein in Sorghum Chocolate (Sorghum bicolor L. Moench) by Ampok Fermentation Method (Doctoral dissertation, Brawijaya University); 2009.

12. Bjelakovic G, Nikolova D, Gluud LL, Simonetti RG, Gluud C. Mortality in randomized trials of antioxidant supplements for primary and secondary prevention: Systematic review and meta-analysis. JAMA 2007;297:842-57.

13. Halliwell B, Gutterige JM. Free Radical in Biology and Medicine. $3^{\text {rd }}$ ed. London: Oxford University Press; 2007.

14. Kale MA, Bindu SM, Khadkikar P. Role of antioxidants and nutrition in oxidative stress: A review. Int J Appl Pharm 2015;7:1-4.

15. Moss GP. Humulene Derivate Sesquiterpenoid Biosynthesis International Union of Biochemistry and Molecules Biology Enzyme Nomenclature; 2011. Available from: http://www.enzyme-database. org/reaction/terp/humul.html. [Last accessed on 2012 Mar 20; Last cited on 2011 Apr 10].

16. Suhartono E, Setiawan B, Edyson R. Test the antioxidant activity 
of Morinda citrifolia juice and its role as an inhibitor of advanced glycation end products (Ditharbonyl compounds) due to glycosylation reaction. Period Med Sci 2005;37:1-6.

17. Tirosh A, Rudich A, Bashan N. Regulation of glucose transportersImplications for insulin resistance states. J Pediatr Endocrinol Metab 2000;13:115-34

18. Ulrich P, Cerami A. Protein glycation, diabetes, and aging. Rec Progress Horm Res 2001;56:1-22.

19. Wittmann I, Ceriello A. Are insulin resistance and atherosclerosis the consequences of oxidative stress? Diabetologia 1996;39:1002-3.

20. Robinson KR. Organic Compounds of High Plant. $6^{\text {th }}$ ed. Bandung: Kosasih Padmawinata, Bandung Technic Institute; 1998.

21. Masharani U, Karam JH, German MS. Pancreatic hormones and diabetes mellitus. In: Greenspan FS, Gardner DG, editors. Basic and Clinical Endocrinology. $7^{\text {th }}$ ed. New York: McGraw-Hill; 2004. p. 658-746.

22. Araki E, Nishikawa T. Oxidative stress: A cause and therapeutic target of diabetic complications. J Diabetes Invest 2010;1:90-6

23. Ronald K. Etiology and pathogenesis of Type 2 diabetes mellitus and related disorders. In: Becker KL, editors. Endocrinology and Metabolism. $3^{\text {rd }}$ ed. Philadelphia, PA: Lippincott Williams \& Wilkins; 2001. p. 1315-27.

24. Soetmadji DJ. The role of free radical in management of type 2 diabetic patients. Disampaikan Pada Symposium Free Radicals in Diabetes and Their Interaction With Sulphonylurea. Jakarta; 2001.

25. Silalahi J. Free radicals and antioxidant vitamins in degenerative diseases. J Indon Med Assoc 2001;51:16-21.

26. Jain AM, Sinha PR, Jain AN, Vavilala SI. Estimation of flavonoid content, polyphenolic content and antioxidant potential of different parts of Abrusprecatorius (L.). Int J Pharm Pharm Sci 2015;7:157-63.

27. Widyawati DP, Werdani WD, Setiakusumo C, Kartikasari A. In vitro antioxidant capacities and antidiabetic properties of Pluchea leaves and green tea mixtures at various proportions. Int J Pharm Pharm Sci 2017;9:203-8 